IIUC STUDIES

ISSN 1813-7733

Vol.- 9, December 2011

(p 307-322)

\title{
The Need for Computer Ethics Course for the Students of CSE/CS or Equivalent Discipline in Bangladesh
}

\author{
Md. Monirul Islam* \\ Mohammed Shamsul Alam ${ }^{* *}$ \\ Tanveer Ahsan $^{* * *}$
}

\begin{abstract}
Ethics has long been a part of engineering education and practices. Computer Science and Engineering (CSE) is not an exception. In this study, however, it was revealed that very few universities of Bangladesh have a course on Computer Ethics in their respective curriculum of Computer Science and Engineering. But the scenario of other countries are completely different; many universities in the world offer courses like Computer Ethics, Social and Ethical Implications of Computing or courses with similar title and content. There is an increasing trend towards teaching ethics as a major course within CSE departments. This paper examines the necessity of incorporating a Computer Ethics course in the curriculum of CSE in the universities of Bangladesh and suggests an outline for the course. It suggests some topics that can be covered in a Computer Ethics course and offers some practical suggestions also for making the course an effective one. This study also examines ethics in computer education in the light of the Holly Quran and the Sunnah of the Prophet Muhammad (S).
\end{abstract}

Keywords: Computer Ethics, Internet Ethics, Computer Crime, CSE/CS, Islamic Ethics

\section{Introduction}

Ethics deals with the standards of human conduct that direct the behavior of individuals and groups. These standards, in turn, are developed by the society within which the individual or group exists

\footnotetext{
* Associate Professor, Department of Computer Science and Engineering, IIUC

** Associate Professor, Department of Computer Science and Engineering, IIUC

*** Assistant Professor, Department of Computer Science and Engineering, IIUC
} 
[1]. Ethics are moral standard that help to guide behavior, actions, and choices. Everybody is responsible and accountable for his/her action and for the consequences it leaves on the society. So, action must be guided by some ethical values to ensure that it maintains certain moral, social and legal standards. Hence, ethics has a practical and significant role to play in engineering education and practice and CSE is not an exception.

Computer Science has advanced rapidly in the last several decades, and this advance necessitates the continual revision of the curriculum for an evolving discipline. One of the fundamental changes in computer science in the last decade is the realization that the context in which technology is used must be taken into account in its design, partly because of the ethical implications of its use, and partly because understanding the context of use helps inform and improve the design [2]. This paper will discuss the importance of teaching Computer Ethics in the department of computer science in all universities of Bangladesh to overcome the ethical issues facing all over the world.

\section{Literature Review}

In order to receive accreditation by ABET's Computing Accreditation Commission, a program must meet various intents. Standard IV-17 states, "There must be sufficient coverage of social and ethical implications of computing to give students an understanding of a broad range of issues in this area [3].”

One of the study intend to expand to the contents of Computer Ethics Syllabus at the departments of Computer Science, Computer Engineering, Mathematics, Engineering in Computing, or similar departments at the universities in Spain and Portugal. This study has been focused on higher education, and therefore, analyzed the three degrees that are offered at Spain and Portugal universities: Computer Science, Management of Information Systems, Information Systems Engineering. The facts revealed on this study are that only 64 universities on Spain have Faculties or Schools of Computer Science. From these 64 universities 91\% responded, drawing the following results: 53 percent of the respondent universities with Computer Science programs do not have Computer Ethics, Computer Law or similar courses. And only the 38 percent of the respondent universities with Computer Science programs have Computer Ethics and/or Computer Law. [4]. 
Computer professionals have specialized knowledge and often have positions with authority and respect in the community. For this reason, they are able to have a significant impact upon the world, including many of the things that people value. Along with such power to change the world comes the duty to exercise that power responsibly. Computer professionals find themselves in a variety of professional relationships with other people, including: employer to employee, client to professional, professional to professional, professional to society. These relationships involve a diversity of interests, and sometimes these interests can come into conflict with each other. Responsible computer professionals, therefore, will be aware of possible conflicts of interest and try to avoid them [5].

Professional organizations in the USA, like the Association for Computing Machinery (ACM) and the Institute of Electrical and Electronic Engineers (IEEE), have established codes of ethics, curriculum guidelines and accreditation requirements to help computer professionals understand and manage ethical responsibilities. For example, in 1991 a Joint Curriculum Task Force of the ACM and IEEE adopted a set of guidelines (“Curriculum 1991”) for college programs in computer science. The guidelines say that a significant component of computer ethics should be included in undergraduate education in computer science [6].

In addition, both ACM and IEEE have adopted Codes of Ethics for their members. The most recent ACM Code includes "general moral imperatives", such as "avoid harm to others" and "be honest and trustworthy". And also included are "more specific professional responsibilities" like "acquire and maintain professional competence" and "know and respect existing laws pertaining to professional work." The IEEE Code of Ethics includes such principles as "avoid real or perceived conflicts of interest whenever possible" and "be honest and realistic in stating claims or estimates based on available data.”

The Accreditation Board for Engineering Technologies (ABET) has long required an ethics component in the computer engineering curriculum. And in 1991, the Computer Sciences Accreditation Commission/Computer Sciences Accreditation Board (CSAC/CSAB) also adopted the requirement that a significant component of computer ethics be included in any computer sciences degree granting program that is nationally accredited [7]. It is clear that professional 
organizations in computer science recognize and insist upon standards of professional responsibility for their members.

\section{Objectives of The Study}

Online fraud, software piracy, hacking, cracking, Phishing, Internet crime, cheating through email or social websites like Facebook etc. are the common problems facing all over the world. These problems are not created by the ordinary people but the computer experts. Besides cyber law and other cautions, to learn computer ethics is also one of the important factors to overcome the problems. This study aims to examine the perceived benefits of teaching Computer Ethics in the computer sciences curricula in Bangladesh universities. The study focuses on:

1. The negative impact of lack of ethics in computer professional on the society.

2. The amount of financial losses caused by ethical problems.

3. The list of universities currently teaching Computer Ethics courses.

4. Ethics in computer education in the light of the Holly Quran and the Sunnah.

5. Proposal of 'Computer Ethics' course for the CSE students in Bangladesh with subject matter.

\section{Methodology}

Since our objective is to introduce Computer Ethics related materials to the CSE curriculum, so we have studied CSE department course curriculum of various universities in Bangladesh as well as other countries. This paper basically based on statistical data. It also makes a brief analysis of the traditional theories and fundamental concepts of ethics in general.

First it will study the computer related problems currently we are facing particularly the economical losses and social disorders. The second part examines ethics in computer education in the light of the Holly Quran and the Sunnah of the Prophet Muhammad (S). The last part attempts to propose Computer Ethics course with proper materials for making the course successful and for effective learning.

\section{Negative Impact of Lack of Ethics in Computer Profession on the Society}

The following ethical issues giving a negative impact to the user of computer and computer related technologies: 


\subsection{Ethics in Systems and Network Administration}

System Administrator is a key person in every computer network and Internet environment. They will strive to build and maintain a safe, healthy, and productive workplace. They will access private information on computer systems only when it is necessary in the course of technical duties. But in our country we have experienced that some system administrators are keeping record of all personal uses of computer as well as Internet.

\subsection{Ethics in Software Engineering}

Software engineers shall act in a manner that is in the best interests of their client and employer consistent with the public interest. They shall ensure that their products and related modifications meet the highest professional standards possible. But some of the software development organizations are making little or no modifications and selling the same products to others.

\subsection{Ethics in Using Computer at Office or Educational Institute}

The users of computer will not divulge passwords, pins, private keys or similar elements to anyone else, and they will not exploit sessions left open or otherwise misappropriate or steal the identity of another user. But users are violating this ethical teachings most of the time.

\subsection{Online Fraud}

Frauds in online commerce lead to lose billions of dollars. Here are the estimated revenues lost due to e-commerce fraud and the percent of total online revenues transacted they constitute.

Table 1: Revenue lost through on line fraud [8]

\begin{tabular}{|c|c|c|}
\hline Year & Billion US\$ & \% of Total Fraud \\
\hline 2000 & 1.5 & 3.6 \\
\hline 2001 & 1.7 & 3.2 \\
\hline 2002 & 2.1 & 2.9 \\
\hline 2003 & 1.9 & 1.7 \\
\hline 2004 & 2.6 & 1.8 \\
\hline 2005 & 2.8 & 1.6 \\
\hline 2006 & 3.1 & 1.4 \\
\hline 2007 & 3.7 & 1.4 \\
\hline 2008 & 4.0 & 1.4 \\
\hline 2009 & 3.3 & 1.2 \\
\hline
\end{tabular}




\subsection{Complain of Internet Crime:}

In December 2003, the Internet Fraud Complaint Center (IFCC) was renamed the Internet Crime Complaint Center (IC3). These filings were composed of complaints primarily related to fraudulent and nonfraudulent issues on the Internet. These complaints were composed of many different fraud types such as auction fraud, non-delivery, and credit/debit card fraud as well as non-fraudulent complaints such as computer intrusions, spam/unsolicited e-mail, and child pornography etc.

Table 2: Number of Complains of Internet Crime [9]

\begin{tabular}{|c|c|}
\hline Year & Number of complaints \\
\hline 2000 & 16838 \\
\hline 2001 & 50412 \\
\hline 2002 & 75064 \\
\hline 2003 & 124515 \\
\hline 2004 & 207449 \\
\hline 2005 & 231493 \\
\hline 2006 & 207492 \\
\hline 2007 & 206884 \\
\hline 2008 & 275284 \\
\hline
\end{tabular}

\subsection{Using Pirated Software}

Unauthorized copying, installation, use, or sale of software is the software piracy. Using pirated software is not only unethical but also illegal. It is a moral and ethical issue. Software piracy takes several forms. The most common method involves making a copy of a program to give to a friend. Seems innocent enough but it is illegal.

Table: 3 Ten Highest and Lowest Country Wise Percentage of Software Piracy [10]

\begin{tabular}{|l|l|c|c|l|c|}
\hline & \multicolumn{2}{|c|}{ Highest } & \multicolumn{2}{c|}{ Lowest } \\
\hline No & Country & \% & No & Country & \% \\
\hline 1 & Armenia & $93 \%$ & 1 & Switzerland & $25 \%$ \\
\hline 2 & Moldova & $92 \%$ & 2 & Austria & $25 \%$ \\
\hline 3 & Azerbaijan & $92 \%$ & 3 & Denmark & $25 \%$ \\
\hline 4 & Bangladesh & $\mathbf{9 2 \%}$ & 4 & Belgium & $25 \%$ \\
\hline 5 & Zimbabwe & $91 \%$ & 5 & Sweden & $25 \%$ \\
\hline 6 & Sri Lanka & $90 \%$ & 6 & Finland & $25 \%$ \\
\hline 7 & Yemen & $89 \%$ & 7 & Japan & $23 \%$ \\
\hline 8 & Libya & $88 \%$ & 8 & New Zealand & $22 \%$ \\
\hline
\end{tabular}


The Need for Computer Ethics Course for the Students of CSE/CS or Equivalent Discipline in Bangladesh

\begin{tabular}{|l|l|c|c|l|c|}
\hline 9 & Venezuela & $87 \%$ & 9 & Luxembourg & $21 \%$ \\
\hline 10 & Iraq & $85 \%$ & 10 & USA & $20 \%$ \\
\hline
\end{tabular}

The piracy rate is the total number of units of pirated software deployed in 2007 divided by the total units of software installed. From the above chart we can see that the United States of America is the least pirated software user on the other hand Armenia has the highest number of pirated software user followed by Moldova, Azerbaijan, and Bangladesh.

\section{Computer Ethics Courses Currently Teaching}

\section{1: Computer Ethics Courses Teaching in the USA}

About 200 colleges and universities in the United States have baccalaureate computer science programs accredited by ABET's Computing Accreditation Commission. In order to receive accreditation, a program must meet various intents; one of the conditions is that they must be sufficient coverage of social and ethical implications of computing. The following table shows the name of the universities that are teaching computer ethics or related courses for CSE students. The numbers of universities teaching this course in all over the world are increasing day by day.

Table 4: List of Universities Offering Computer Ethics courses in USA [11]

\begin{tabular}{|l|l|}
\hline Name Of The University & Name Of The University \\
\hline Arizona State University & University of Alabama \\
\hline Boise State University & University of California \\
\hline Bucknell University & University of Central Florida \\
\hline East Tennessee State University & University of Colorado \\
\hline Eastern Washington State Univ. & University of Idaho \\
\hline Florida Atlantic University & University of Louisiana \\
\hline George Mason University & University of Mississippi \\
\hline Grambling State University & University of Nebraska \\
\hline Indiana University & University of Nevada \\
\hline Kennesaw State University & University of New Hampshire \\
\hline Millersville Univ. of Pennsylv. & University of New Orleans \\
\hline Montana State University & University of Oklahoma \\
\hline Nicholls State University & University Pacific \\
\hline Northeastern University & University South Alabama \\
\hline Radford University & University South Florida \\
\hline
\end{tabular}




\begin{tabular}{|l|l|}
\hline North Dakota State University & Univ. of Tennessee \\
\hline Oregon State University & University of West Georgia \\
\hline Southern Illinois University & University of Wyoming \\
\hline Southwest Missouri State Univ. & Utah State University \\
\hline Texas Christian University & Winthrop University \\
\hline
\end{tabular}

\section{2: Computer Ethics Courses Teaching in Bangladesh}

The scenario is completely different in Bangladesh. There are very few universities in Bangladesh offering 'Impact of Computer on Society' and 'Special Topics in IT/CSE' etc. courses to their CSE students. The following courses are currently teaching for CSE students in Bangladesh:

Table 5: Common CSE Related Courses Teaching in Bangladesh [12, $13,14]$

\begin{tabular}{|l|l|}
\hline Course Title & Course Title \\
\hline Intro. to Computer Systems & Basic Graph Theory \\
\hline Discrete Mathematics & Fault Tolerant Systems \\
\hline Structured Program. Language & Digital Image Processing \\
\hline Object Oriented Programming & Basic Multimedia Theory \\
\hline Data Structures & Algorithm Engineering \\
\hline Digital Logic Design & Wireless Networks \\
\hline Algorithms & Computational Geometry \\
\hline Theory of Computation & Machine Learning \\
\hline Assembly Language & Computer Interfacing \\
\hline Database & Business Law \\
\hline Computer Architecture & Pattern Recognition \\
\hline Software Engineering & Digital Image Processing \\
\hline Compiler & Digital Signal Processing \\
\hline Data Communication & Ecommerce \\
\hline Operating System & Cryptography, Network Security \\
\hline Microproc. \& Microcontrollers & Communication Engineering \\
\hline Numerical Methods & Parallel \& Dist. Processing \\
\hline Computer Networks & Simulation and Modeling \\
\hline Software Development & Internet and Web Technology \\
\hline Artificial Intelligence & VLSI Design \\
\hline Digital System Design & Pattern Recognition \\
\hline Computer Graphics & Project and Thesis \\
\hline &
\end{tabular}


The Need for Computer Ethics Course for the Students of CSE/CS or Equivalent Discipline in Bangladesh

\section{Computer Ethics from an Islamic View}

The Quran is a book of guidance, which contains general principles applicable to all times and places. Here we relate ethical and professional code of conduct with relevant verses of the Holly Qur'an and the Hadith of the Prophet Muhammad (S) [15]. ACM (Association for Computing Machinery) Code of Ethics and Professional Conduct represents ACM's commitment to promoting the highest professional and ethical standards, and makes it incumbent on all ACM Members to [16]:

\section{A). Contribute to Society and Human Well-Being.}

This principle concerning the quality of life of all people affirms an obligation to protect fundamental human rights and to respect the diversity of all cultures. An essential aim of computing professionals is to minimize negative consequences of computing systems, including threats to health and safety.

Allah says in the Holly Qur'an: "Do not do mischief on earth after it hath been set in order, but call on him with fear and longing (in your hearts): for the mercy of Allah is (always) near to those who do good" (7:56).

\section{B). Avoid Harm to Others.}

This principle prohibits use of computing technology in ways that result in harm to any of the following: users, the general public, employees and employers.

Allah says in the Holly Qur'an: "And withhold not things justly due to men, nor do evil in the land, working mischief” (26:183).

\section{C). Be Honest and Trustworthy.}

A computer professional has a duty to be honest about his or her own qualifications, and about any circumstances that might lead to conflicts of interest.

Allah says in the Holly Qur'an: "Ye who believe! Fear Allah and be with those who are truthful” (13:119).

\section{D). Be Fair and take Action not to Discriminate.}

Discrimination on the basis of race, sex, religion, age, disability, national origin, or other such factors is an explicit violation of ethical policy and will not be tolerated.

Allah says in the Holly Qur'an: "O ye who believe! stand out firmly for Allah, as witnesses to fair dealing, and let not the hatred of others to you make you 
swerve to do wrong and depart from justice. Be just, for this is close to piety: and fear Allah. For Allah is well-Acquainted with all that ye do (5:8)".

\section{E). Honor Property Rights Including Copyrights and Patent.}

Violation of copyrights, patents, trade secrets and the terms of license agreements are prohibited by law in most circumstances. Copies of software should be made only with proper authorization. Unauthorized duplication of materials must not be condoned.

\section{F). Give Proper Credit for Intellectual Property.}

Computing professionals are obligated to protect the integrity of intellectual property. Specifically, one must not take credit for other's ideas or work, even in cases where the work has not been explicitly protected by copyright, patent, etc.

Allah says in the Holly Qur'an: O you who believe!

Do not consume your property among yourselves unjustly unless it be a trade amongst you, by mutual consent. And do not kill yourselves (nor kill one another). Surely, Allah is Most Merciful to you (4:29).

The Prophet (S) says "Allah likes a person who masters his/her job or profession” (Al-Bukhari).

\section{G). Respect the Privacy of Others.}

There is increased potential for violating the privacy of individuals and groups. It is the responsibility of professionals to maintain the privacy and integrity of data describing individuals.

Allah says in the Holly Qur'an: O ye who believe! avoid suspicion as much (as possible): for suspicion in some cases is a sin: and spy not on one another, nor speak ill of each other behind their backs. Would any of you like to eat the flesh of his dead brother? Nay, ye would abhor it. . . But fear Allah: for Allah is oftReturning, most Merciful (49:12).

\section{H). Honor Confidentiality.}

The ethical concern is to respect all obligations of confidentiality to employers, clients, and users unless discharged from such obligations by requirements of the law or other principles of this Code.

Allah says in the Holly Qur'an: "Those who faithfully observe their trusts and their covenants" (23:8) 
Prophet Muhammad (S) said "whoever guards the secret of a Muslim, Allah will guard his secret in this life and on resurrection day"

As a computer professional, we must have good intention to contribute to the society and human well-being. Above Qur'anic verses and Hadith of the prophet Muhammad (S) is a clear emphasis on being ethical in all the circumstances while using the computer resources.

\section{Proposed Course 'Computer Ethics' and its Brief Outline}

\subsection{Title of the Course}

a) Computer Ethics

b) Computer, Ethics and Society

\subsection{Credit Hours and Contact Hours}

For the students of CSE/CS the course will be a 3 credit hours course. Typically the length of the course will be 14 weeks. Each week consists of three 50 minutes class periods. The course can be offered as 1 credit, 1.5 credits, 2 credits or 3 credits course for other departments.

\subsection{Objectives of the Course}

The course is aimed at enabling students to focus on the humanitarian, social, and cultural impact of computer technology by focusing on ethical issues faced by and brought about by computing professionals, including those related to networking and the internet, intellectual property, privacy, security, computer risks and responsibilities, ethics in the work place and future technology.

\subsection{Course Outline:}

ACM and IEEE adopted a set of guidelines ("Computer Science Curriculum 2008”) for undergraduate programs in computer science. [17] Cecil Schmidt and Robert J. Boncella also suggest a course outline in their paper. [18] Incorporating these guidelines/suggestions a course outline of Computer Ethics is proposed below assuming that it will be offered for senior students.

\section{Topic 1: Introduction}

Objective of this chapter is to understand the overall foundation of computer ethics course. The main topics will discuss are the History of computer hardware, software, networking; Overview of Technological Change; Discussion on some moral problems caused by information technology. 
Topic 2: Introduction to Ethics

Objective of this chapter is to define computer ethics and to understand that the Computer Ethics is a branch of practical philosophy which deals with how computing professionals should make decisions regarding professional and social conduct. The main topics will discuss here are what is Ethics? Basic Philosophical Ethics: Consequentialism, Deontologism, Social Contract Theory; Scientific ethics in historical perspective.

Topic 3: Some Moral Problems related with Internet

Internet Privacy is one of the key issues that have emerged since the evolution of the Internet. Internet users often expose personal information on the Internet in order to sign up or register for thousands of different possible things. The main topics will discuss here are Spam, Pornography, Censorship, Free speech etc.

\section{Topic 4: Intellectual Property}

The objective of this chapter is to discuss about Intellectual property (IP) which refers to creations of the mind: inventions, literary and artistic works, and symbols, names, images, and designs used in commerce. The main topics will discuss here are: What is intellectual property" Copyrights, patents, and trade secrets; Software piracy; Software patents; What is fair use? Debate on Open source etc.

\section{Topic 5: Privacy}

The objective of this chapter is to discuss the privacy. Computer privacy can exist in many different forms. This refers to the security of the information on computer from files to what we do on the Internet. The topics will cover here are: What is privacy? How does computer technology effect privacy? To what moral problems does this lead? Ethical and legal basis for privacy protection; Privacy implications of database systems; Technological strategies for privacy protection; Freedom of expression in cyberspace.

\section{Topic 6: Computer Crime}

The objective of this chapter is to discuss about Computer crime which refers to any crime that involves a computer and a computer network. The topics will discuss are: History of computer crime; Different types of computer crime; "Cracking" ("hacking") and its effects; Viruses, Spam, Fraud, Threats, Worms, and Trojan horses; Identity theft; moral issues related to these crimes. 
Topic 7: Computer \& Software Reliability

The objective of this chapter is to discuss about Computer and Software Reliability which refer the probability of failure hardware and software operation for a specified period of time in a specified environment. The topics will discuss are: How liability is determined when computer hardware and software fails? Responsibility vs. Liability vs. Accountability; Some historical examples of software risks.

Topic 8: Computer in the Workplace.

Today's offices look very different from those in the early days. Information technology is replacing energy as society's main resource. The objective of this chapter is to discuss what are the some of the ethical issues that have arisen as a result of using computers in the workplace? Are They Used Ethically? What are the effects of monitoring work place computer? What are employer obligations with regard to healthy computing environment (ergonomics)? What is the “digital divide?” Should it be resolved? Can it be resolved?

\section{Topic 9: Professional Code of Ethics}

A code of professional conduct is a necessary component to any profession to maintain standards for the individuals within that profession to adhere. Professional code of ethics is a necessary because it brings about accountability, responsibility and trust to the individuals that the profession serves. This chapter will Examine and discuss professional codes of ethics, conduct, and practice (IEEE, ACM, SE, AITP, and so forth). Are they fair? Are they effective?

Topic 10: Computer Ethics: Islamic perspective.

The purpose of this chapter is to study the ethical behavior in Islamic perspective in an attempt to stop many unethical practices such as software piracy, software intellectual property violations and general software development. It will also discuss: How law, ethics, and religion interlink? Islamic Ethics; Discussion on computer ethics based on the Holly Qur' an and the Hadith.

\subsection{Instructor}

Ethics is a branch of philosophy. So there is a long debate that who will teach 'Computer Ethics' course, Philosophy teacher or CSE teacher. Many computer science faculty members may be reluctant to raise moral issues in the context of the computer science classes they are teaching. That being the case, there is the very real possibility that if ethics is taught by faculty members in philosophy, computer science students 
may never have the experience of seeing a computer science professor "doing ethics." When computer science faculty members teach ethics, they serve as role models who demonstrate that contemplating the ethical dimensions of everyday decisions is something that everyone can and should do [19]. It is proper that the CSE teacher will teach the course and some may need special study on this topic.

\section{Conclusion}

Technology is something that changes rapidly. New tools and techniques are coming out every day. Consequently, people are faced with new ways of dealing with the society. However, it also makes possible doing thing in a wrong way which, as a whole, may not fit with the ethical standards the people in the society accept and adhere to. People generally are not very aware of the consequences of the use of a technology. But, they are affected and feel the result of applying a technology when it comes out. So, the duty to ensure that the things do not go in a wrong way primarily goes to the people who are technically sound and they must be aware of moral and ethical values as well. It would be better if departments view ethics course as important as other core topics in the computer science curriculum. Making ethics a priority would have a variety of beneficial consequences. It will enable the learners more motivated to improve their understanding of ethical theories and their ability to evaluate ethical dilemmas. In Bangladesh, Computer ethics course need to include in CSE/CS or relevant discipline because ethics is a motivation to do good. Besides that cyber law is not properly enacted here yet. If an ethics course is implemented and taught effectively it will make the proponents of technology socially more aware and will help to reduce the bad consequences the technology casts on the society. 
The Need for Computer Ethics Course for the Students of CSE/CS or Equivalent Discipline in Bangladesh

\section{REFERENCES}

1. Bottorff, D.L., 'How Ethics Can Improve Business Success', in Annual Editions: Business Ethics 00/01, McGraw Hill, 2000, p.11-15.

2. Bynum, T. W. and Maner, W. (Eds.). 'Proceedings of the National Conference on Computing and Values’, 1991, New Haven, CT. 1991

3. Computing Accreditation Commission. (2004). Criteria for Accrediting Computing Programs, ABET, Inc.

4. Zanatta, Alexandre Lazaretti, 'Teaching Computer Ethics at Spain and Portugal Universities' .

http://bibliotecavirtual.clacso.org.ar/ar/libros/raec/ethicomp5/docs/pdf_papers/40 Lazaretti\%20Zanatta,\%20Alexandre.pdf

5. Johnson, D., Computer Ethics, 3", ed., Prentice Hall, Englewood Cliffs, NJ, 2001.

6. Turner, A.J. (1991), "Summary of the ACM/IEEE-CS Joint Curriculum Task Force Report: Computing Curricula, 1991,” Communications of the ACM, 34(6): 69-84.

7. Conry, S. (1992), "Interview on Computer Science Accreditation,” in T. Bynum and J. Fodor (creators), Computer Ethics in the Computer Science Curriculum (a video program), Kingston, NY: Educational Media Resources, Inc.

8. Anand, E-commerce Fraud: Estimated Online Revenue Loss 2010

http://gorumors.com/crunchies/ecommerce-fraud-revenue-loss/

9. Internet Crime Report, Bureau of justice assistance

http://www.ic3.gov/media/annualreport/2008_IC3Report.pdf

10. http://www.nationmaster.com/graph/cri_sof_pir_rat-crime-software-piracyrate\#source

11. Michael J. Quinn, 'On Teaching Computer Ethics within a Computer Science Department’ Science and Engineering Ethics, Volume 12, Issue 2, 2006 pp. 342

12. CSE Course Curriculum, BUET, http://www.buet.ac.bd/cse/undergrad/courses.php

13. CSE Course Curriculum, CUET http://www.cuet.ac.bd/course.php?dep_code=CSE

14. CSE Course Curriculum, DU http://www.univdhaka.edu/department/academic_program/index.php?bodyid=CSE

15. Mansoor Al-A'ali, "Computer ethics for the computer professional from an Islamic point of view", Journal of Information, Communication and Ethics in Society, Emerald Group Publishing Limited Vol. 6 Iss: 1, pp.28 - 45, 2008.

16. ACM Code of Ethics and Professional Conduct http://www.acm.org/about/codeof-ethics 
IIUC Studies, Vol. 9

17. Computer Science Curriculum 2008: An Interim Revision of CS 2001 http://www.computer.org/education/cc2008/

18. C. Schmidt, R. J. Boncella, "A Framework for an Ethics Course for the Information Technology Students” www.iacis.org/iis/2006_iis/PDFs/Schmidt_Boncella.pdf

19. Michael J. Quinn, 'On Teaching Computer Ethics within a Computer Science Department' Science and Engineering Ethics, Volume 12, Issue 2, 2006 pp. 342

20. The Holly Quran, English meaning translation, By Abdullah Yusuf. 